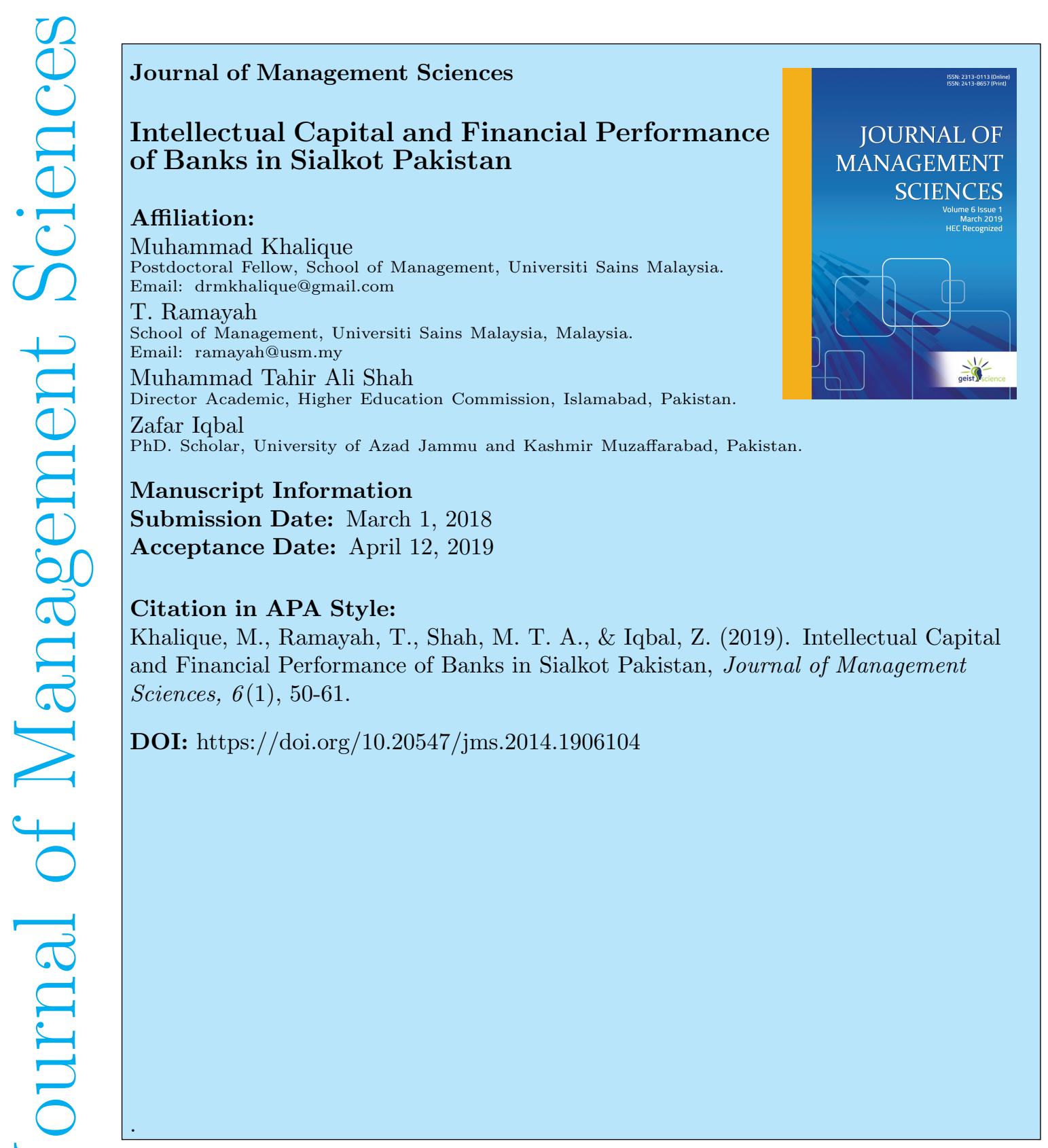




\title{
Intellectual Capital and Financial Performance of Banks in Sialkot
}

\section{Pakistan}

\author{
Muhammad Khalique * \\ T. Ramayah ${ }^{\dagger}$ \\ Muhammad Tahir Ali Shah \\ Zafar Iqbal $\S$
}

\begin{abstract}
The main aim of this research is to determine the impact of intellectual capital on the financial performance of banking sector operating in Sialkot Pakistan. Integrated intellectual capital model (IICM) was used to achieve the objective of the study. Structured questionnaire survey forms were used to collect the data from the targeted respondents. Purposive sampling technique was used to choose the targeted sample. A total of 210 out of 250 completed and usable questionnaires survey were returned. Six research hypotheses were constructed to address the objectives of this study. Smart PLS 3.0 was used to test the proposed research hypotheses. The findings showed that the three hypotheses were supported while remaining were not. This study will provide a clear understanding about the concept and applications of intellectual capital in banking sector. This study will be a milestone for the potential researchers to conduct their studies in Pakistani context.

Keywords: Intellectual capital, financial performance, Conventional banks, Islamic banks, Pakistan.
\end{abstract}

\section{Introduction}

Due to innovation, improvement and changes in business fields the efficient and effective usage of tangible and intangible resources play a vital role for the success, strength and sustainability of organizations. Knowledge intensive organizations believed that intellectual capital has become the most important asset in measuring and evaluating the organizational performance. Presently size of organizations does not matter but the utilization of its resources efficiently and effectively can enhance the sustainability and profit. More specifically in service sector intangible assets such as intellectual capital (IC) has been secured overwhelming responses and appeared as one of the most important strategic assets for competitive edge (Cohen \& Kaimenakis, 2007; Hsu \& Fang, 2009; Janošević, Dženopoljac, \& Bontis, 2013; Khalique, Shaari, Abdul, \& Isa, 2011). In business field many researchers such as Khalique, Shaari, and Isa (2014); Mention and Bontis (2013) argued that in a knowledge based economy intellectual capital is considered as one of the

\footnotetext{
* Postdoctoral Fellow, School of Management, Universiti Sains Malaysia \& Director MUST Business School, Mirpur University of Science and Technology (MUST), Mirpur, Azad Jammu and Kashmir Pakistan.

Email: drmkhalique@gmail.com

†School of Management, Universiti Sains Malaysia, Malaysia. Email: ramayah@usm.my

${ }^{\ddagger}$ Director Academic, Higher Education Commission, Islamabad, Pakistan.

$\S$ PhD. Scholar, University of Azad Jammu and Kashmir Muzaffarabad, Pakistan.

Acknowledgment: The researchers greatly acknowledged the contribution of Iqra Riaz MS student MUST Business School, Mirpur University of Science and Technology (MUST), to gather the data and literature for this study
} 
supreme and crucial assets for the success and survival of organizations. Further, they argued that in service sector such as banking sector, intangible asset such as intellectual capital has secured great intention for competitive advantage. There is no doubt that in the world the banking sector is recognized as one of the most important sectors in service industry and its contribution towards economic development is highly acknowledged. Intellectual capital is recognized as one of the most important and valuable asset for the banking sector (Khalique et al., 2014; Mention \& Bontis, 2013; Poh, Kilicman, \& Ibrahim, 2018).

Banking industry plays a vital role in the formation of capital and economic development in every country of the world. Finance is the life for organizations and bank is giving out financial sources. Without banks countries' economies cannot grow and sustain. Banks continually raise economic growth and provide facilitation to execute business transactions (Barathi Kamath, 2007; Khalique et al., 2014; Poh et al., 2018). Generally, banks gather capital from those who have surplus and lend to those who then efficiently perform financial services and earn benefits. Today, banks provide lot of services to countries. There is no doubt that the banking sectors development is directly related with economic development and prosperity. Banks have great impact on the country's development and smooth functioning of business activities. Financial sector perform vital role in formation of capital by using different financial techniques (Vuong, Vu, \& Mitra, 2017). Outcomes of various researches and evidences show that financial sector has a positive impact on the economic development (Khalique et al., 2014; Okpara \& Wynn, 2007; Poh et al., 2018). Financial sector are very crucial for any country. Pakistani financial sector, particularly banking industry and insurance companies have great impact of SMEs development. It generates lot of job opportunities. Financial sector of a country make their resources better and use these resources efficiently and in productive ways. In order for the economic growth to reaches it optimal level. Hence financial institutions play a very significant role in economic growth.

In Pakistan, banking sector is based on both conventional and Islamic banks which performing parallel with positive impact on economic development. Banking sector is also referred as knowledge intensive sector which offered service to the customers. Banks play a vital role for the growth and development of the economy and considered as back bone of the economy. Nowadays, as with the customers demand, innovative products and services are the main source to attract customers and it is impossible without capitalization of intellectual capital, innovation and research. Consequently organizations utilize their resources in proper and efficient way. By utilizing intellectual capital, organizations enhance profitability which leads to financial performance of organizations (Kharal, Abrar, Rehma, Khan, \& Kharal, 2014). Many researchers argued that intellectual capital is considered as an important intangible asset to the organizations as it plays effective role to enhance financial performance and also provides competitive advantage to firms.

In earlier studies several researchers pays considerable attention on conventional banking sector to observe the impact of intellectual capital on financial performance such as Barathi Kamath (2007); Khalique, Shaari, Abdul, Isa, and Samad (2013) but the Islamic banking sector was not addressed. Researchers argued that intellectual capital is a prime 
source for success of any organization as it increases the value, profitability, innovation and organizational performance.

In Pakistani context a very few studies were conducted to identify the impact of intellectual capital on the financial performance of banking sector and mostly the policy makers unaware about the importance of intellectual capital. Therefore there is a great need to determine impact of intellectual capital on financial performance for banking sector in Pakistan.

\section{Literature Review and Hypotheses Development}

From last two decades, the notion of intellectual capital has secured overwhelming response from researchers, practitioners, and academicians who addressed the idea and its importance in knowledge-based economy perspectives. Knowledge is considered as one of the most important strategic assets for the success and sustainability of organizations. The foundation of intellectual capital is based on data. Data is a collection of raw facts and figures, and the synthesizing of data into a meaningful way leads to information. The information is a main source of knowledge and the wisdom and judgment mainly come from information. When organizations or individuals able to create value added products and services by using their knowledge it is called intellectual capital. Intellectual capital is a dynamic set of intangible resources. According to Khalique, Shaari, Abdul, Isa, and Ageel (2011), the idea of intellectual capital was first coined by Dunn and Pressman (2005). Intellectual capital refers to soft or intangible assets of organizations. Many researchers explained in different ways that the resources such as knowledge, information, employees' skills and capabilities which organizations put as an input in order to create the wealth. Kang and Snell (2009) stated that intellectual capital is an organizations' knowledge, stock embedded in employees, teams, routines, organizational systems and processes. Khalique (2012) proposed a comprehensive definition of intellectual capital and he argued that "intellectual capital is a is a combination of intangible assets or resources, such as knowledge, know-how, professional skills \& expertise, customer relationships, information, databases, organizational structures, innovations, social values, faith and honesty."

In the early stage of the development of intellectual capital many researchers such as Bontis, Chua Chong Keow, and Richardson (2000); Edvinsson and Sullivan (1996) proposed that intellectual capital is mainly based on three components namely human capital, customer capital and structural capital. In intellectual capital field three components namely social capital, technological capital and spiritual were added (Bueno, Salmador, Rodríguez, \& Martín De Castro, 2006; Ismail, 2005) and finally (Khalique, Shaari, Abdul, \& Isa, 2011) proposed a holistic and widely accepted Integrated Intellectual Capital Model (IICM). Subsequently, this study adopts an Integrated Intellectual Capital Model which is based on six dimensions namely human capital, structural capital, customer capital, social capital, technological capital and spiritual capital as part of the IC constructs. 


\section{Components of Intellectual Capital}

Human capital is considered as the heart of intellectual capital and it includes the education, knowledge, skills competencies, and know-how in certain fields that are important to the success of enterprise and their aptitudes and attitudes. HC also based on employee's learning about job, loyalty, inspiration drive plan, efficiency, and employees training programs. $\mathrm{HC}$ is the dominant predictor of intellectual capital and has significant positive contribution to enhance the performance of organizations (Almossawi, 2001; Barathi Kamath, 2007; Khalique et al., 2014). Customer capital shows the customers loyalty, brand, customer satisfaction and have significant relationship with firm performance, to increase sale with consumer's involvement (Abazeed, 2017). Customer's loyalty and satisfaction build understanding and fulfill customers' needs (Mention \& Bontis, 2013). In business customers are prime source for income generation of organization and it is very necessary for organizations to satisfy their customer needs. Structural capital deals with organizations structures and methods of an organization. It includes procedure, manuals, databases that help the employees to achieve organizational performance (Bontis et al., 2000; Khalique et al., 2014). Bontis et al. (2000) argued that the structural capital is the possessions of the organizations which include databases, process, manufacturing process and routine. It based on all producing process, operational system and organizational environment.

Social capital is identified as the important function for social organizations. Social capital includes features such as norms, social values and networking. Nahapiet and Ghoshal (1998) stated organizations having high social capital can get more competitive advantage. Social capital is a set of human efforts that connect people and cooperate with each other and also a set of social values, norms, social networks which play a vital role in social and economic development. Social capital is glue for the organization. Technological capital is very vital for greater performance and competitive environment for the organizations. It enhance quality, productivity and cost saving. Organizations face different encounters to meet these challenges firms upgrade their technology. Bueno, Paz Salmador, and Rodríguez (2004) argued that technological capital is the set of intangible asset which is based on innovation and technical process. It is based on intellectual property, R\&D and industrial property. Spiritual capital is a new source for organizations to survive in a competitive environment. Spiritual capital indicates intangible assets. Studies indicated that spiritual capital is a religious concept in which employees perform their duties by logic for God. Individuals believe that their honestly services enhanced their outcome. Spiritual capital helps employees to move within their religion it based on ethical values, honesty, and moral values (Ismail, 2005; Khalique, Shaari, \& Isa, 2013).

\section{Importance of Intellectual Capital in Banking Sector}

In intellectual capital field many studies (Barathi Kamath, 2007; Khalique et al., 2014; Tiwari \& Vidyarthi, 2018) found that intellectual capital is one of the most crucial and strategic assets for the success of banking sector. They illustrated that intellectual capital performs a dynamic role for the growth and development of banks. Intellectual capital is 
the fundamental part of knowledge based economy. Therefore, the prominence of intellectual capital cannot be overlooked, specifically in banking sector because this sector is a highly knowledge based sector and its products are mostly innovative. Effective capitalization of intellectual capital is more crucial and pivotal in the success of the banks as compared to other industries operating in the financial system. Banking sector is mostly equipped with intellectual capital tend to provide high quality products and services to the customers which is possible by banks' continuous training of its human resources, building of its brand, internal system and processes, strong social networking, implementation of latest technology, research \& development, and strong moral and ethical values.

\section{Conceptual Framework}

The foundation of this research is based on intellectual capital theory. Intellectual capital theory is mainly based on knowledge based theory and resource based theory (Khalique, Shaari, Abdul, et al., 2013). Intellectual capital theory affirmed that the value creation in products and services are the main source of sustainability and success of organizations in a competitive business environment. This theory is based on the six components of intellectual namely, human capital, customer capital, structural capital, social capital, technological capital and spiritual capital. In this study these six components were used as independent variables while financial performance of banking sector as dependent variable. On the basis of aforementioned discussion following research hypotheses were constructed.

Hypothesis 1: Human capital has significant impact over the financial performance of Islamic banks and conventional banks of Sialkot Pakistan.

Hypothesis 2: Customer capital has significant impact over with the financial performance of Islamic banks and conventional banks of Sialkot Pakistan.

Hypothesis 3: Structural capital has significant impact over the financial performance of Islamic banks and conventional banks of Sialkot Pakistan.

Hypothesis 4: Social capital has significant impact over the financial performance of Islamic banks and conventional banks of Sialkot Pakistan.

Hypothesis 5: Technological capital has significant impact over the financial performance of Islamic banks and conventional banks of Sialkot Pakistan.

Hypothesis 6: Spiritual capital has significant impact over the financial performance of Islamic banks and conventional banks of Sialkot Pakistan. 


\section{Research Methodology}

The main objective of this study is to analyze the impact of intellectual capital on financial performance of Islamic and conventional banks operating in Sialkot Pakistan. The nature of this study is cross sectional and quantitative. Primary data were used to test the proposed research hypotheses. The data were collected through structured questionnaire survey. Saunders, Lewis, and Thornhill (2006) stated that in quantitative research the unit of analysis may be individual, organization, or a family. Therefore, the unit of analysis for this study was the employees of conventional and Islamic banks. The data were gathered from all branches of largest five commercial banks and five Islamic banks operating in Sialkot region. Selected conventional banks namely, Habib Bank Limited, United Bank Limited, Allied Bank Limited, Muslim Commercial Bank and Bank Alfalah, while the Islamic banks were Meezan Bank, Al-Barka Islamic Bank, Bank Islamic Pakistan Limited, Dubai Islamic Bank, and Burj Bank were involved in this study. The research instrument were adopted from Khalique, Bontis, Abdul Nassir bin Shaari, and Hassan Md. Isa (2015). The respondents were selected through purposive sampling technique. A total of 250 sets of structured questionnaire survey forms were distributed to grasp the perception of respondents about the employed constructs. 210 completed sets of questionnaire survey forms were returned which were used for data analysis.

\section{Results}

In this study Smart PLS 3.0 a multivariate technique which can simultaneously evaluate the measurement model and structural model was used. In management sciences smart PLS 3.0 is widely used to analyze the data (Hair, Ringle, \& Sarstedt, 2011). It is a power method of analysis in spite of its minimal demands on sample size and multivariate normality of data. It is also very useful for this study because it provide a better prediction capability. In this study, the measurement model tested reliability and validity of the employed unobserved constructs while structural model was used to test the hypothesized relationship. Bootstrapping (re-samples 500) was used to examine the loadings and path coefficients significance.

\section{Measurement Model}

The convergent validity of the employed constructs was examined by factor loading of average variance extracted (AVE) and composite reliability (CR) (Hair Jr, Hult, Ringle, \& Sarstedt, 2016). The recommended values for loading are set at $>0.6$, the AVE should be $>$ 0.5 and the CR should be $>0.7$. Table 1 reported that the results of the measurement model exceeded the recommended thresholds. Figure 2 depicted that the convergent validity is sufficient. Discriminant validity of the measurement items was examined through the criteria recommended by Fornell and Larcker (1981). Table 2 showed that the square root of the AVE was examined against the inter-correlations of the construct with the other constructs to ensure the discriminant validity (Chin, 1998; Fornell \& Larcker, 1981). The 
results showed that all the square root of the AVE surpassed the correlations with other variables. Therefore, the measurement model is reflected satisfactory with the empirical evidence of adequate reliability, convergent validity and discriminant validity.

Table 1

Results of the Measurement Model

\begin{tabular}{|c|c|c|c|c|c|}
\hline Constructs & Items & Loading & AVE & CR & $\alpha$ \\
\hline \multirow{5}{*}{ Human Capital (HUC) } & HCQ1 & 0.768 & \multirow{5}{*}{0.500} & \multirow{5}{*}{0.831} & \multirow{5}{*}{0.751} \\
\hline & HCQ2 & 0.668 & & & \\
\hline & HCQ3 & 0.713 & & & \\
\hline & HCQ6 & 0.690 & & & \\
\hline & HCQ8 & 0.680 & & & \\
\hline \multirow{4}{*}{ Customer Capital (CUC) } & CUCQ2 & 0.679 & \multirow{4}{*}{0.604} & \multirow{4}{*}{0.858} & \multirow{4}{*}{0.784} \\
\hline & CUCQ4 & 0.768 & & & \\
\hline & CUCQ5 & 0.814 & & & \\
\hline & CUCQ6 & 0.837 & & & \\
\hline \multirow{4}{*}{ Structural Capital (STC) } & SCQ2 & 0.678 & \multirow{4}{*}{0.582} & \multirow{4}{*}{0.846} & \multirow{4}{*}{0.755} \\
\hline & SCQ3 & 0.802 & & & \\
\hline & SCQ4 & 0.879 & & & \\
\hline & SCQ6 & 0.671 & & & \\
\hline \multirow{3}{*}{ Social Capital (SOC) } & SOCQ1 & 0.774 & \multirow[b]{3}{*}{0.613} & \multirow[b]{3}{*}{0.824} & \multirow[b]{3}{*}{0.709} \\
\hline & SOCQ44 & 0.737 & & & \\
\hline & SOCQ5 & 0.787 & & & \\
\hline \multirow{5}{*}{ Technological Capital (TEC) } & TECQ1 & 0.770 & \multirow{5}{*}{0.645} & \multirow{5}{*}{0.901} & \multirow{5}{*}{0.871} \\
\hline & TECQ3 & 0.833 & & & \\
\hline & TECQ4 & 0.841 & & & \\
\hline & TECQ6 & 0.825 & & & \\
\hline & TECQ7 & 0.743 & & & \\
\hline \multirow{5}{*}{ Spiritual Capital (SPC) } & SPCQ2 & 0.860 & \multirow{5}{*}{0.608} & \multirow{5}{*}{0.820} & \multirow{5}{*}{0.663} \\
\hline & SPCQ3 & 0.621 & & & \\
\hline & SPCQ44 & 0.836 & & & \\
\hline & SPCQ5 & 0.739 & & & \\
\hline & SPC6 & 0.540 & & & \\
\hline \multirow{4}{*}{ Financial Performance (FP) } & FPQ1 & 0.787 & \multirow{4}{*}{0.561} & \multirow{4}{*}{0.836} & \multirow{4}{*}{0.739} \\
\hline & FPQ3 & 0.750 & & & \\
\hline & FPQ4 & 0.736 & & & \\
\hline & FPQ5 & 0.720 & & & \\
\hline
\end{tabular}

Table 2

Discriminant Validity (Fornell and Larcker Criteria)

\begin{tabular}{lccccccc}
\hline Constructs & CUC & FP & HUC & SOC & SPC & STC & TEC \\
\hline Customer Capital (CUC) & $\mathbf{0 . 7 7 7}$ & & & & & & \\
Financial Performance (FP) & 0.703 & $\mathbf{0 . 7 4 9}$ & & & & & \\
Human Capital (HUC) & 0.637 & 0.63 & $\mathbf{0 . 7 0 7}$ & & & & \\
Social Capital (SOC) & 0.399 & 0.623 & 0.402 & $\mathbf{0 . 7 8 3}$ & & & \\
Spiritual Capital (SPC) & 0.665 & 0.417 & 0.56 & 0.141 & $\mathbf{0 . 7 8}$ & & \\
Structural Capital (STC) & 0.521 & 0.679 & 0.726 & 0.616 & 0.365 & 0.763 & $\mathbf{0 . 8 0 3}$ \\
\hline Notes: The off-diagonal values are the correlations between the latent constructs and \\
diagonal are square; values of AVEs.
\end{tabular}


Figure 1

The Measurement Model

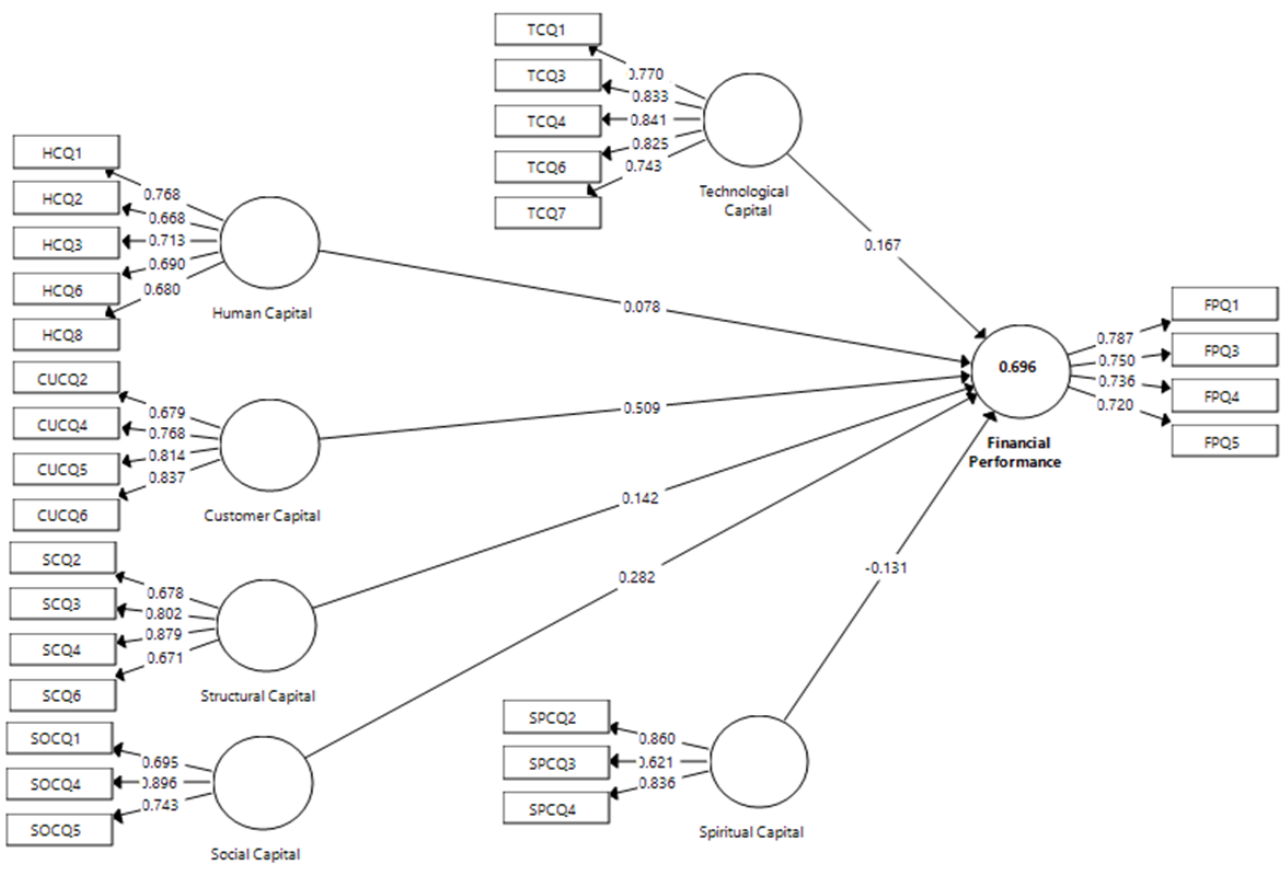

\section{Structural Model}

In PLS multiple indices are required to examine the acceptance or rejection of the research hypotheses. These indices are recommended based on their quality and ability to explain the data congruence and precision are the $R^{2}$ value for exogenous to endogenous relationships, and regression weights or path coefficients (Fornell \& Larcker, 1981). Furthermore, Falk and Miller (1992) argued that these indices provide evidence for the existence of relationships between the latent variables. To examine the significance of the path coefficients and calculate the standard errors bootstrapping (re-samples 500 were generated from 210 cases) was used. The overall model showed that the $R^{2}$ value is 0.696 which reported that $69.6 \%$ of total variance explained by these six components of intellectual capital to enhance the financial performance of Islamic and conventional banks in Sialkot Pakistan. Results of research hypotheses are shown in Table 3. The path coefficients along with their $\mathrm{t}$-values provided direct evidence of the hypotheses accepted or rejected. In Table 3 the results reveal that the path coefficients between human capital and financial performance $(\beta=0.078, t=0.989, \mathrm{p}>0.05)$, structural capital and financial performance $(\beta=0.142, \mathrm{t}=$ $1.824, \mathrm{p}>0.05)$ and spiritual capital $(\beta=-0.1 .31, \mathrm{t}=1884, \mathrm{p}>0.05)$ appeared as insignificant predictors. However, customer capital $(\beta=0.509, \mathrm{t}=5.648, \mathrm{p}<0.05)$, social capital $(\beta=0.282, \mathrm{t}=4.400, \mathrm{p}<0.05)$ and technological capital $(\beta=0.167, \mathrm{t}=3.109, \mathrm{p}<0.05)$ appeared as significant contributors. The empirical findings show that the outcomes sup- 
porting research hypotheses $H_{2}, H_{4}, H_{5}$ where $H_{1}, H_{2}$ and $H_{6}$ are not and not supporting. The results of research hypotheses are shown in Table 3.

\begin{tabular}{llllc}
$\begin{array}{l}\text { Table } 3 \\
\text { Results of hypotheses testing }\end{array}$ & & & \\
\hline Hypothesis & Relationship & $\beta$ & t-Values & Supported \\
\hline H1 & Human Capital $\rightarrow$ Financial Performance & 0.07 & 0.996 & No \\
H2 & Customer Capital $\rightarrow$ Financial Performance & 0.51 & 5.648 & Yes \\
H3 & Structural Capital $\rightarrow$ Financial Performance & 0.14 & 1.824 & No \\
H4 & Social Capital $\rightarrow$ Financial Performance & 0.28 & 4.400 & Yes \\
H5 & Techno. Capital $\rightarrow$ Financial Performance & 0.17 & 3.109 & Yes \\
H6 & Spiritual Capital $\rightarrow$ Financial Performance & -0.13 & 1.884 & No \\
\hline Note: Significant at p 0.05. & & &
\end{tabular}

\section{Discussion and Implications}

The main objective of this study was to determine the impact of intellectual capital on the financial performance of banking sector in Sialkot Pakistan. To achieve the objective of this research a total of 210 respondents were involved. Using a structured survey approach and the Smart PLS 3.0 path analysis the study has found support for the proposed integrated intellectual capital model. The empirical findings illustrated that banking sector in Sialkot believed that intellectual capital is very important for their financial performance. Regarding the components of intellectual capital results showed that customer capital, social capital and technological capital appeared as the significant contributors in the model. Customer capital was appeared as the most significant predictor and it reflects that banking sector considered it as the most crucial for financial performance. However, human capital, structural capital and spiritual capital were seemed to be insignificant contributors in model. Muhammad and Ismail (2009) found that the human capital and structural capital individually were not significantly related to the company's performance. It reflects that the banking sector is not giving them significant importance. Surprisingly spiritual capital appeared as negative contributor but not significant. It showed that due to some Islamic religious background some individuals do not prefer banking job and due to interest (riba) they assumed that the spiritual capital is not much important for the financial performance.

This study contributes in threefold: first the extension and application of the concept of intellectual capital in banking sector in Pakistan. Findings showed that the overall intellectual capital is very important for the financial performance of banking sector in Sialkot Pakistan. The findings of this study are consistent with the previous studies such as Khalique et al. (2014). Second, the empirical examination of the research showed that three components of intellectual capital namely customer capital, social capital and technological capital were appeared as significant contributors while three components such as human capital, structural capital and spiritual capital were performed insignificant contributors. Banking sector required to make more investment and arrange training and development programs to strengthen these components. Many researchers (Cohen \& Kaimenakis, 2007; Seleim, Ashour, \& Bontis, 2004; Sharabati, Naji Jawad, \& Bontis, 2010) argued that these components are very important for the success of organizations as well 
as for the financial performance. Third: the above empirical findings and its implications are in line with the theory of intellectual capital. Findings demonstrates that the theory developed and confirmed in the others sector is also applicable in the banking sector. This theory propose that those organization having all the components of intellectual capital as significant contributors are capable with more strength to compete in the business as compared to those which possess only a single or few IC components. Moreover, this theory has implications for the policy makers, managers and stakeholders of banking sector as well for service sector.

\section{Limitations and Directions for Future Research}

Like other studies, this research also has some of its limitations. First, this study has targeted on a single service sector namely banking sector. Findings of this research will be situation specific due to limited sample size. Second, the study is cross-sectional in nature, longitudinal research can be better to understand the impact of intellectual capital on financial performance of banks. Third the study has used the purposive sampling technique to identify the sample for the study. Therefore, the concerned parties are advised to use the findings of the study with cautions. This study recommend to further potential researchers to address the aforementioned limitations and extend the sample size of their study. 


\section{References}

Abazeed, R. A. M. (2017). The impact of intellectual capital dimensions on organizational performance of public hospitals in Jordan. Global Journal of Management And Business Research, 17(5), 1-11.

Almossawi, M. (2001). Bank selection criteria employed by college students in Bahrain: An empirical analysis. International Journal of Bank Marketing, 19(3), 115-125.

Barathi Kamath, G. (2007). The intellectual capital performance of the Indian banking sector. Journal of Intellectual Capital, 8(1), 96-123.

Bontis, N., Chua Chong Keow, W., \& Richardson, S. (2000). Intellectual capital and business performance in Malaysian industries. Journal of Intellectual Capital, 1(1), 85-100.

Bueno, E., Paz Salmador, M., \& Rodríguez, Ó. (2004). The role of social capital in today's economy: Empirical evidence and proposal of a new model of intellectual capital. Journal of Intellectual Capital, 5(4), 556-574.

Bueno, E., Salmador, M. P., Rodríguez, Ó., \& Martín De Castro, G. (2006). Internal logic of intellectual capital: A biological approach. Journal of Intellectual Capital, 7(3), 394405.

Chin, W. W. (1998). The partial least squares approach to structural equation modeling. Modern Methods for Business Research, 295(2), 295-336.

Cohen, S., \& Kaimenakis, N. (2007). Intellectual capital and corporate performance in knowledge-intensive SMEs. The Learning Organization, 14(3), 241-262.

Dunn, S. P., \& Pressman, S. (2005). The economic contributions of John Kenneth Galbraith. Review of Political Economy, 17(2), 161-209.

Edvinsson, L., \& Sullivan, P. (1996). Developing a model for managing intellectual capital. European Management Journal, 14(4), 356-364.

Falk, R. F., \& Miller, N. B. (1992). A primer for soft modeling. United States: University of Akron Press.

Fornell, C., \& Larcker, D. F. (1981). Evaluating structural equation models with unobservable variables and measurement error. Journal of Marketing Research, 18(1), 39-50.

Hair, J. F., Ringle, C. M., \& Sarstedt, M. (2011). PLS-SEM: Indeed a silver bullet. Journal of Marketing Theory and Practice, 19(2), 139-152.

Hair Jr, J. F., Hult, G. T. M., Ringle, C., \& Sarstedt, M. (2016). A primer on partial least squares structural equation modeling (PLS-SEM). United States: Sage publications.

Hsu, Y.-H., \& Fang, W. (2009). Intellectual capital and new product development performance: The mediating role of organizational learning capability. Technological Forecasting and Social Change, 76(5), 664-677.

Ismail, M. (2005). The influence of intellectual capital on the performance of telekom malaysia (Unpublished doctoral dissertation). Universiti Teknologi Malaysia.

Janošević, S., Dženopoljac, V., \& Bontis, N. (2013). Intellectual capital and financial performance in Serbia. Knowledge and Process Management, 20(1), 1-11.

Kang, S.-C., \& Snell, S. A. (2009). Intellectual capital architectures and ambidextrous learning: A framework for human resource management. Journal of Management Studies, 46(1), 65-92. 
Khalique, M. (2012). Impact of intellectual capital on the organizational performance of selected small and medium enterprises in Malaysia and Pakistan. Unpublished PhD Thesis, Universiti Malaysia Sarawak.

Khalique, M., Bontis, N., Abdul Nassir bin Shaari, J., \& Hassan Md. Isa, A. (2015). Intellectual capital in small and medium enterprises in Pakistan. Journal of Intellectual Capital, 16(1), 224-238.

Khalique, M., Shaari, J. A. N. B., \& Isa, A. H. B. M. (2013). The road to the development of intellectual capital theory. International Journal of Learning and Intellectual Capital, 10(2), 122-136.

Khalique, M., Shaari, J. A. N. B., \& Isa, A. H. B. M. (2014). Determining the influence of intellectual capital on the organisational performance of banking sector in Kelantan, Malaysia. International Journal of Learning and Intellectual Capital, 11(4), 306-319.

Khalique, M., Shaari, N., Abdul, J., \& Isa, A. H. B. M. (2011). Intellectual capital and its major components. International Journal of Current Research, 3(6), 343-347.

Khalique, M., Shaari, N., Abdul, J., Isa, A. H. B. M., \& Ageel, A. (2011). Role of intellectual capital on the organizational performance of electrical and electronic SMEs in Pakistan. International Journal of Business and Management, 6(9), 253-257.

Khalique, M., Shaari, N., Abdul, J., Isa, A. H. B. M., \& Samad, N. (2013). Impact of intellectual capital on the organizational performance of Islamic banking sector in Malaysia. Asian Journal of Finance \& Accounting, 5(2), 75-83.

Mention, A.-L., \& Bontis, N. (2013). Intellectual capital and performance within the banking sector of Luxembourg and Belgium. Journal of Intellectual Capital, 14(2), 286-309.

Muhammad, N. M. N., \& Ismail, M. K. A. (2009). Intellectual capital efficiency and firm's performance: Study on Malaysian financial sectors. International Journal of Economics and Finance, 1(2), 206-212.

Nahapiet, J., \& Ghoshal, S. (1998). Social capital, intellectual capital, and the organizational advantage. Academy of Management Review, 23(2), 242-266.

Okpara, J. O., \& Wynn, P. (2007). Determinants of small business growth constraints in a sub-Saharan African economy. SAM Advanced Management Journal, 72(2), 24.

Poh, L. T., Kilicman, A., \& Ibrahim, S. N. I. (2018). On intellectual capital and financial performances of banks in Malaysia. Cogent Economics E Finance, 6(1), 1453574.

Saunders, M., Lewis, P., \& Thornhill, A. (2006). Research methods for business students. India: Pearson Education.

Seleim, A., Ashour, A., \& Bontis, N. (2004). Intellectual capital in Egyptian software firms. The Learning Organization, 11(4/5), 332-346.

Sharabati, A.-A. A., Naji Jawad, S., \& Bontis, N. (2010). Intellectual capital and business performance in the pharmaceutical sector of Jordan. Management Decision, 48(1), 105-131.

Tiwari, R., \& Vidyarthi, H. (2018). Intellectual capital and corporate performance: A case of Indian banks. Journal of Accounting in Emerging Economies, 8(1), 84-105.

Vuong, N. B., Vu, T. T. Q., \& Mitra, P. (2017). Impact of capital structure on firm's financial performance: Evidence from United Kingdom. Journal of Finance and Economics Research, 2(1), 16-29. 